\title{
Korelati korištenja medija kod djece predškolske dobi
}

Slavica Šimić Šašić** ssimic@unizd.hr

http://orcid.org/0000-0002-4465-1716

Marija Rodićn

marijarodic1@outlook.com

https://orcid.org/0000-0003-4050-9191 https://doi.org/10.31192/np.19.1.12

UDK: $316.774-053.4$

303.62-055.52

Prethodno priopćenje /

Preliminary communication Primljeno: 19. kolovoza 2020. Prihvaćeno: 6. studenog 2020.

Cilj istraživanja bio je ispitati povezanost izmedu količine vremena provedenog u korištenju medija djece predškolske dobi i nekih osobnih i okolinskih čimbenika. U istraživanju je sudjelovalo 391 dijete u dobi od 5 do 7 godina. Roditelji su procijenili korištenje medija, temperament i regulaciju emocija kod djece, roditeljska ponašanja prema djetetu i roditeljsku kompetentnost. Odgojiteljice su procijenile socioemocionalnu dobrobit i otpornost djece, a procjene o samopoimanju prikupile su kroz intervjue s djecom. Dobiveni rezultati pokazuju da je količina vremena koju djeca predškolske dobi provode u korištenju medija slabo, ali statistički značajno povezana s osobnim i okolinskim čimbenicima. Spol djeteta, negativan afekt, regulacija emocija, obrazovanje roditelja, popustljivost, informatička pismenost i stav prema dječjem korištenju medija povezani su s djetetovim ukupnim vremenom provedenim u korištenju medija. Korelati vremena provedenog $u$ korištenju medija razlikuju se $i$ ovise o vrsti medija. Rezultati istraživanja ukazuju na potrebu daljnjeg istraživanja uloge medija izmedu varijabli antecedenti i razvojnih ishoda.

Ključne riječi: djeca predškolske dobi, mediji, osobni i okolinski čimbenici, roditelji.

\footnotetext{
* Izv. prof. dr. sc. Slavica Šimić Šašić, Sveučilište u Zadru, Odjel za izobrazbu učitelja i odgojitelja, Ulica dr. Franje Tuđmana 24i, HR-23000 Zadar.

*** Marija Rodić, mag. paed., Sveučilište u Zadru, Odjel za izobrazbu učitelja i odgojitelja, Ulica dr. Franje Tuđmana 24i, HR-23000 Zadar.
} 


\section{Uvod}

Svaka nova generacija djece odrasta $u$ tehnološki i medijski bogatijem svijetu, stoga odgojni stručnjaci tehnologiju i medije uvrštavaju u važan sekundarni socijalizacijski čimbenik. ${ }^{1}$ Tradicionalni mediji (televizija, radio, časopisi) dopunjeni su novim digitalnim tehnologijama koje omogućuju interakciju i brz pristup zabavi, informacijama, znanju, socijalnim kontaktima itd. Korištenje tehnologije dječje je svakodnevno iskustvo te da ga moramo uzeti u obzir kao razvojni okvir. ${ }^{2}$

\section{Izloženost djece medijima}

Istraživanja pokazuju naglo povećanje dostupnosti i izloženosti djece digitalnoj tehnologiji i medijima. Postotak djece u Americi koja imaju pristup mobilnom telefonu povećao se od $52 \%$ u 2011., $75 \%$ u 2013. ${ }^{3}$ do 96,6 \% u 2015. ${ }^{4}$ Djeca u Hrvatskoj prate svjetske trendove. Pokazalo se da gotovo nema obitelji s predškolskom djecom koja u svom kućanstvu nema televizor, mobitel i računalo (99,9 \%, 98,2 \% i 99,9\%), 85 \% kućanstava ima tablet, 65 \% igraće konzole, a prosječan broj elektroničkih uređaja po kućanstvu je šest. Sva djeca koriste barem jedan elektronički uređaj, 97,2 \% djece gleda televiziju, više od dvije trećine djece koristi mobitel i tablet, 60 \% djece se koristi računalom, a jedna četvrtina djece koristi igraće konzole.

Najveći postotak djece pred različitim ekranima dnevno provede do jednog sata: 40,2 \% gleda televiziju, 53,8 \% gleda video sadržaje putem mobitela, tableta ili računala, 42,7 \% igra igrice putem mobitela ili računala. Predškolska djeca pred ekranom u prosjeku provedu 2,4 sata radnim danom, te tri sata vikendom. Preciznije, pred malim ekranima više od dva sata dnevno provede $50 \%$ djece u dobi od dvije do tri godine (vikendom $52 \%$ ), $60 \%$ djece u dobi od četiri do pet godina (vikendom $76 \%$ ), te $71 \%$ djece u dobi od šest do sedam godina (vikendom $82 \%$ ). Djeca elektroničke uređaje počinju koristiti vrlo rano (40 \% djece od godinu dana, $79 \%$ djece od druge godine, a u dobi od četiri godine čak

${ }^{1}$ Usp. V. ILIŠIN, A. MARINOVIĆ BOBINAC, F. RADIN, Djeca i mediji: uloga medija u svakodnevnom životu djece, Zagreb, Državni zavod za zaštitu obitelji, materinstva i mladeži i Institut za društvena istraživanja, 2001, 1-182, 32.

2 Usp. N. MIKELIĆ PRERADOVIĆ, G. LEŠIN, M. ŠAGUD, Investigating Parents' Attitudes towards Digital Technology Use in Early Childhood: A Case Study from Croatia, Informatics in Education, 15 (2016) 1,127-146, 1.

${ }^{3}$ Usp. V. RIDEOUT, Zero to Eight. Children's Media Use in America (28.10.2013) https:// www.commonsensemedia.org/research/zero-to-eight-childrens-media-use-in-america-2013 (08.08.2020).

${ }^{4}$ Usp. H. KABALI i dr., Exposure and use of mobile media devices by young children, (19.01.2017) https://alcott.concordps.org/jpeachey/wp-content/uploads/sites/4/2016/05/Pediatrics_November2015.pdf (18.08.2020). 
97 \%). Prvi uređaj s kojim su se susreli je bio televizor, zatim mobitel i tablet. Autori ovog istraživanja zaključuju da su djeca aktivna u korištenju elektroničkih uređaja, većina (97 \%) predškolske djece zna samostalno uključiti neki elektronički uređaj, 90 \% njih samostalno traži i pokreće sadržaje koje žele, 45 $\%$ ih samostalno koristi internet. ${ }^{5}$

\subsection{Utjecaji medija na djecu}

Novi oblici medija uvijek su plašili roditelje, odgajatelje i učitelje, pa se i današnji razvoj informacijske tehnologije često smatra prijetnjom. $S$ jedne strane imamo shvaćanja o negativnom, a s druge strane shvaćanja o pozitivnom utjecaju medija na razvoj djece. Istraživanja su utvrdila vezu između pretjeranog gledanja televizije $u$ ranom djetinjstvu i kašnjenja u kognitivnom, jezičnom i socioemocionalnom razvoju. ${ }^{6}$ Pretpostavlja se da su uzroci ovim ishodima izloženost neprikladnim sadržajima, namijenjenima odraslim osobama, smanjena interakcija s roditeljima i slabije obiteljsko funkcioniranje. Također su utvrđene skromne, ali značajne veličine učinka izlaganja medijskom nasilju na agresivno ponašanje, misli, osjećaje, ${ }^{7}$ učinak reklama na razvoj stereotipa, ${ }^{8}$ povezanost korištenja medija i pretilosti, problema sa spavanjem, pažnjom, te negativan utjecaj na socijalizaciju i razvoj jezika. ${ }^{9}$

Korištenje medija oduzima vrijeme za aktivnosti kao što su čitanje i hobiji, te smanjuje sudjelovanje u društvenim aktivnostima izvan kuće. Rani početak korištenja medija, više sati provedenih uz medije, te nekvalitetan sadržaj kod predškolaca su značajni prediktori lošijeg izvršnog funkcioniranja (kontrole impulsa, samoregulacije, mentalne fleksibilnosti), ${ }^{10}$ kao i sposobnosti razumijevanja drugih. ${ }^{11}$ Američka pedijatrijska akademija ne preporuča izlaganje djece mlađe od dvije godine medijima jer je smanjena mogućnost učenja bez interakcije s odraslima. S druge strane, dokazani su pozitivni utjecaji izlože-

\footnotetext{
${ }^{5}$ Usp. Poliklinika za zaštitu djece i mladih Grada Zagreba i Hrabri telefon, Prvo nacionalno istraživanje o predškolskoj djeci pred malim ekranima (01.06.2017), https://www.poliklinikadjeca.hr/istrazivanja/prvo-nacionalno-istrazivanje-o-predskolskoj-djeci-pred-malim-ekrani$\mathrm{ma} /(08.08 .2020)$.

${ }^{6}$ Usp. Y. REID CHASSIAKOS i dr., Children and Adolescents and Digital Media, Pediatrics, 138 (2016) 5:e20162593, e6.

7 Usp. B. BUSHMAN, R. HUESMANN, Short-term and Long-term Effects of Violent Media on Aggression in Children and Adults, Archives of Pediatric and Adolescent Medicine, 160 (2006) 348-352; 348.

${ }^{8}$ Usp. Ilišin, Djeca i mediji..., 26.

9 Usp. AAP COUNCIL ON COMMUNICATIONS AND MEDIA, Media and Young Minds, Pediatrics, 138 (2016) 5:e20162591, 2.

${ }^{10}$ Usp. A. NATHANSON i dr., The relation between television exposure and executive function among preschoolers, Developmental Psychology, 50 (2014) 5, 1497-1506.

${ }^{11}$ Usp. A. NATHANSON i dr., The relation between television exposure and theory of mind among preschoolers, Journal of Communication, 63 (2013) 6, 1088-1108.
} 
nosti medijima djece starije od dvije godine. ${ }^{12}$ Visokokvalitetni sadržaji mogu potaknuti razvoj pismenosti, računanja i prosocijalnih vještina. ${ }^{13}$ Utvrđen je utjecaj televizije na stjecanje širokog spektra novih znanja, akademskih, komunikacijskih i interpersonalnih vještina, te na pobuđivanje novih interesa. ${ }^{14}$ Izloženost prosocijalnim medijima povezana je s višom razinom prosocijalnog ponašanja, empatijske zabrinutosti i nižim razinama agresivnog ponašanja. ${ }^{15}$

Digitalna tehnologija može pomoći djeci u vizualizaciji teških koncepata i stvaranju okruženja u kojem djeca mogu naučiti kroz akciju, pružajući im mogućnost stvaranja i istraživanja. ${ }^{16}$ Naglašavaju se prednosti igranja video igara, koje mogu poboljšati kognitivne vještine, utjecati na ustrajnost, poboljšati raspoloženje, socijalne vještine i ishode učenja. ${ }^{17}$ Štoviše, govori se o potrebi uvođenja pozitivne medijske psihologije i dodatnih istraživanja pozitivnih utjecaja medija na djecu i adolescente, jer su istraživanja više usmjerena na negativne efekte. $^{18}$

Potter $^{19}$ zaključuje da medijski utjecaji mogu biti kratkoročni i dugoročni, te da djeluju na znanje, stavove, emocije, fiziološke reakcije i ponašanje. Danas najprihvaćenija teorija ograničenih efekata naglašava da mediji utječu na ponašanje pojedinca, ali je taj utjecaj posredovan i limitiran drugim čimbenicima. ${ }^{20}$ Uzrast je specifično obilježje koje mlađu djecu čini ranjivijima jer se sposobnost razumijevanja sadržaja kojima su djeca izložena drastično razlikuje kod različite dobi. Svakako se s uzrastom povećava količina vremena koju djeca provode uz medije, te postoje razlike u sadržajima koje konzumiraju dječaci i djevojčice u skladu s rodnim ulogama. ${ }^{21}$ Roditelji energičnije djece češće koriste medije da

\footnotetext{
${ }^{12}$ Usp. Reid Chassiakos, Children and Adolescents..., e5.

${ }^{13}$ Usp. D. ANDERSON i dr. Early childhood television viewing and adolescent behavior: the recontact study, Monographs of the Society for Research in Child Development, 66 (2001) 1, 1-147; D. CHRISTAKIS i dr., Modifying media content for preschool children: a randomized controlled trial, Pediatrics, 131 (2013) 3, 431-438.

${ }^{14}$ Usp. B. CLIFFORD i dr., Television and Children. Programme Evaluation, Comprehension and Impact, Hillsdale, NJ, Lawrence Erlbaum Associates, 1995 prema Ilišin, Djeca i mediji..., 26.

${ }^{15}$ Usp. S. COYNE i dr., A meta-analysis of prosocial media on prosocial behavior, aggression, and empathic concern: A multidimensional approach. Developmental Psychology, 54 (2018) 2, 331-347, 331.

${ }^{16}$ Usp. Mikelić Preradović, Investigating Parents' Attitudes..., 130.

${ }^{17}$ Usp. I. GRANIC, A. LOBEL, R. ENGELS, The Benefits of Playing Video Games, American Psychologist, 69 (2013) 1, 66-78.

${ }^{18}$ Usp. R. de LEEUW, M. BUIJZEN, Introducing positive media psychology to the field of children, adolescents, and media, Journal of Children and Media, 10 (2016) 1, 39-46, 41.

${ }^{19}$ Usp. J. POTTER, Review of Literature on Media Literacy, Sociology Compass, 7 (2013) 6, $417-$ $435,10.1111 /$ soc4.12041 (10.08.2020).

${ }^{20}$ Usp. J. LULL, Media, Communication, Culture: A Global Approach, Cambridge, UK, Polity Press, 2000, 101.

${ }^{21}$ Usp. Ilišin, Djeca i mediji...,132-164; Poliklinika za zaštitu djece i mladih Grada Zagreba, Prvo nacionalno istraživanje...; J. SINDIK, Kako roditelji percipiraju utjecaj medija na predškolsku djecu?, Medijska istraživanja, 18 (2012) 1, 5-33.
} 
bi se djeca opustila, kao nagradu ili da bi oni imali vrijeme za sebe. ${ }^{22}$ Pretjerano gledanje televizije vjerojatnije je kod djece teškog temperamenta, ${ }^{23}$ djece koja imaju problema sa samoregulacijom. ${ }^{24}$ Veća je vjerojatnost da će maloj djeci sa socioemocionalnim problemima biti dan mobitel da bi ih se smirilo. ${ }^{25}$ Utvrđeno je da emocionalna regulacija nije povezana s izloženošću televiziji kod djece $u$ dobi od pet do 12 godina, ali je negativno povezana sa zahtjevima za kupnjom nekih proizvoda i sukobima s roditeljima oko kupnje tih proizvoda. ${ }^{26}$ Utvrđeno je da postoji povezanost između korištenja medija i samopoštovanja, ali taj odnos ovisi o spolu i dobi djece. ${ }^{27}$ Također je utvrđeno da povećana razina korištenja elektroničkih medija predviđa lošiju dobrobit (psihološko funkcioniranje), te da su ishodi lošiji za gledanje televizije nego za igranje igrica i korištenje računala. ${ }^{28}$ Djeca iz siromašnijih, niže obrazovanih i nepotpunih obitelji više gledaju televiziju, dok djeca bogatijih i obrazovanijih roditelja više koriste tiskane medije i kompjutore. Djeca lošijeg školskog uspjeha više koriste sve masovne medije, osim kompjutora i knjiga, a djeca koja su sklonija jednom mediju istodobno više koriste i ostale medije. ${ }^{29}$ Djeca iz bogatijih obitelji češće gledaju edukativne sadržaje od djece iz siromašnijih obitelji. ${ }^{30}$ Djeca medije najčešće koriste radi zabave, posebice mala djeca i djeca iz siromašnijih obitelji. ${ }^{31}$ Na uzorku predškolske djece u Hrvatskoj ${ }^{32}$ utvrđeno je da djeca starijih majki, nezaposlenih očeva više gledaju televiziju, djeca starijih roditelja više koriste računalo, vještija su u radu na računalu, bolje poznaju internet, te više igraju edukativne igrice na računalu. Više obrazovanje obaju roditelja negativno je povezano s gledanjem sadržaja koji nisu primjereni djeci, a pozitivno s vreme-

\footnotetext{
${ }^{22}$ Usp. R. NABI, M. KRCMAR, It takes two: the effect of child characteristics on U.S. parents' motivations for allowing electronic media use, Journal of Children and Media, 10 (2016) 3, 285-303, 298.

${ }^{23}$ Usp. A. THOMPSON, L. ADAIR, M. BENTLEY, Maternal characteristics and perception of temperament associated with infant TV exposure, Pediatrics 131(2013) 2, e390-7.

${ }^{24}$ Usp. J. RADESKY i dr. Infant self-regulation and early childhood media exposure. Pediatrics, 133 (2014) 5, 1172-1178, 1176.

${ }^{25}$ Usp. J. RADESKY i dr., Use of mobile technology to calm upset children: associations with social-emotional development. JAMA Pediatrics, 170 (2016) 4, 397-399, 397.

${ }^{26}$ Usp. M. LAPIERRE, E. ROZENDAAL, A Cross-National Study Examining the Role of Executive Function and Emotion Regulation in the Relationship between Children's Television Exposure and Consumer Behavior, Journal of Youth and Adolescence, 48 (2019), 1980-2004.

${ }^{27}$ Usp. N. MARTINS, K. HARRISON, Racial and gender differences in the relationship between children's television use and self-esteem a longitudinal panel study communication research. Communication Research, 39 (2012) 3, 338-357; S. BRAIG i dr., Screen Time, Physical Activity and Self-Esteem in Children: The Ulm Birth Cohort Study, (16.06.2018) https://www.mdpi. com/1660-4601/15/6/1275/htm (18.08.2020).

${ }^{28}$ Usp. T. HINKLEY i dr., Early Childhood Electronic Media Use as a Predictor of Poorer Wellbeing. A Prospective Cohort Study, JAMA Pediatrics, 168 (2014) 5, 485-492, 485.

${ }^{29}$ Usp. D. ROBERTS i dr., Kids \& media @ the new millennium. Menlo Park, CA: Henry J. Kaiser Family Foundation, 1999, prema Ilišin, Djeca $i$ mediji..., 21.

${ }^{30}$ Usp. Rideout, Zero to Eight...

${ }^{31}$ Usp. Kabali, Exposure and use of mobile media...

${ }^{32}$ Usp. Sindik, Kako roditelji percipiraju...19-20.
} 
nom koje dijete dnevno provodi uz računalo, vještinom djetetova rada na računalu, igranjem edukativnih igrica na računalu. Broj djece $u$ obitelji općenito je značajno pozitivno povezan s vremenom koje dijete provodi pred televizorom, računalom i konzolom za igru. Kvaliteta roditeljstva može modificirati odnos između korištenja medija i dječjeg razvoja: neprikladan sadržaj i nekonzistentno roditeljstvo imaju kumulativne negativne efekte, dok toplo roditeljstvo i edukativni sadržaji imaju aditivne benefite za izvršne funkcije siromašne predškolske djece. ${ }^{33}$

Mediji po sebi nisu ni dobri ni loši, bitan je način na koji se koriste. Teorija zadovoljenja potreba ${ }^{34}$ pretpostavlja da ljudi aktivno koriste masovne medije za zadovoljenje specifičnih potreba (informiranje, razvijanje socijalnih odnosa, potvrdivanje osobnog identiteta, zabava, bijeg od realnosti itd.). Iz takvog pristupa proizlazi da ljudi medije i njihove sadržaje koriste selektivno, birajući ritam korištenja, sadržaje po temama, autorima i slično, što upućuje na aktivan odnos i ograničenost medijskog utjecaja na primatelje. U tom kontekstu bitno je razvijati medijsku pismenost koja pridonosi da djeca uče razlikovati fikciju i stvarnost, da znaju birati sadržaje, kritički pristupati prezentiranom sadržaju, prepoznavati pozitivne i negativne strane medija, ${ }^{35}$ pri čemu važnu ulogu u razvoju medijske pismenosti imaju roditelji. Samo medijski pismeni roditelji mogu razvijati medijsku pismenost kod djece. Roditelji mogu koristiti različite strategije da bi kontrolirali, nadgledali ili interpretirali sadržaj medija djeci, a najčešće strategije medijacije su: zajedničko gledanje, restriktivna medijacija (postavljanje ograničenja) i aktivna medijacija (raspravljanje o sadržajima). ${ }^{36}$ Roditelji u Hrvatskoj su prosječno informirani o medijima, informiraniji su obrazovaniji roditelji, te češće primjenjuju sve oblike medijacije. ${ }^{37}$ Također je utvrđena pozitivna povezanost između stavova i korištenja medija kod djece, roditelja i učitelja, a roditelji i učitelji imaju izraženiju percepciju opasnosti koje internet može imati na djecu nego percepciju korisnih aspekata. Visokoobrazovani roditelji češće smatraju da internet može unaprijediti dječje znanje, vještine i sposobnosti. ${ }^{38}$

\footnotetext{
${ }^{33}$ Usp. D. LINEBARGER i dr., Associations between parenting, media use, cumulative risk, and children's executive functioning, Journal of Developmental \& Behavioral Pediatrics, 35 (2014) 6, 367-377.

${ }^{34}$ Usp. Ilišin, Djeca i mediji..., 18.

${ }^{35}$ Usp. B. GUNTER, J. McALEER, Children \& Television, London - New York, Routledge, 1997, 222.

${ }^{36}$ Usp. L. SCHOFIELD CLARK, Parental Mediation Theory for the Digital Age, Communication Theory, 21 (2011) 323-343, 326.

${ }^{37}$ Usp. S. BARTAKOVIĆ, J. SINDIK, Medijacijska uloga roditelja prilikom djetetovog gledanja televizije, Acta Iadertina, 13 (2016) 2, 95-113, 103-104.

${ }^{38}$ Usp. J. PREGRAD i dr., Iskustva i stavovi djece, roditelja i učitelja prema elektroničkim medijima, Zagreb, Ured UNICEF-a za Hrvatsku, 2010, 1-54, 21-29.
} 


\subsection{Cilj i problemi istraživanja}

Dosadašnja istraživanja u Hrvatskoj, uglavnom su bila usmjerena na utvrđivanje prevalencije korištenja medija kod djece predškolske dobi, te razlike s obzirom na sociodemografske čimbenike. U ovom se istraživanju željelo dodatno ispitati povezanost korištenja medija s obilježjima temperamenta, regulacijom emocija, samopoimanjem i socioemocionalnom dobrobiti i otpornosti kod djece predškolske dobi, te roditeljskim ponašanjem i percepcijom roditeljske kompetentnosti. Stoga je cilj ovog istraživanja bio ispitati povezanost između količine vremena provedenog u korištenju medija djece predškolske dobi i nekih njihovih osobnih čimbenika (spol, dob, temperament, regulacija emocija, samopoimanje, socioemocionalna dobrobit i otpornost) zatim okolinskih (dob, obrazovanje, zaposlenost roditelja, mjesto življenja, broj djece, ponašanja roditelja, roditeljska kompetentnost, informatička pismenost i stav roditelja prema korištenju medija). Očekuje se povezanost između količine vremena koje dijete provede u korištenju medija i osobnih i okolinskih čimbenika.

\section{Metoda}

\subsection{Ispitanici}

Istraživanje je provedeno na prigodnom uzorku. Sudjelovalo je 391 dijete predškolske dobi, isto toliko njihovih roditelja, te 123 odgojiteljice s područja Zadra, Murtera, Splita, Otočca i Korenice. Dječaka je bilo 52,44 \%, a djevojčica $47,56 \%$. Djeca su bila stara od pet do sedam godina, a prosječna dob bila je 5,86 godina. Majke su činile 82,10 \% uzorka, očevi 11,22 \%, dok 6,65 \% roditelja nije odgovorilo na pitanje o roditelju koji procjenjuje dijete. Prosječna dob roditelja bila je 36,93 godine. Većina majki je završila fakultet $(50,94)$, a očeva srednju školu (56,53\%). Većina roditelja $82,86 \%$ je zaposlena, $8,18 \%$ radi povremeno, $6,91 \%$ nije zaposleno. Većina obitelji 78,26 \% živi u gradu, a 19,69 \% na selu. Dvoje djece ima 52,43 \% roditelja. Prosječna dob odgojiteljica bila je 42,66 godina. Njih 82,66 \% je završilo dvogodišnji ili trogodišnji stručni studij, 13,28 \% trogodišnji preddiplomski studij, 2,98 \% ima završen diplomski studij, a 1,08 \% srednju školu.

\subsection{Mjerni instrumenti primijenjeni na uzorku roditelja}

Anketni upitnik općih podataka i korištenja medija - pitanja su se odnosila na sociodemografska obilježja djece i roditelja, dječja iskustva korištenje medija, roditeljsku informatičku pismenost i stav o dječjem korištenju medija. 
Upitnik dječjeg ponašanja ${ }^{39}$ - validiran za potrebe ovog istraživanja. Originalno sadrži 36 tvrdnji. Faktorskom analizom potvrđena je trofaktorska struktura upitnika, s tim da nisu sve čestice imale zadovoljavajuća faktorska zasićenja originalnim faktorom. Formirani su ukupni rezultati za skraćene supskale: surgenciju (pr. tvrdnje: Često juri u nove situacije; uključene tvrdnje: 4., 7., 13., 16., 25., 31.), negativan afekt (Ako je spriječeno u nečemu što želi, postane jako frustrirano; 2., 5., 8., 14., 17., 19., 23., 29., 32., 35.) i kontrolu ulaganja napora (Pokazuje iznimnu koncentraciju prilikom bojanja ili crtanja; 3., 6., 12., 15., 18., 21., 24., 36.). Tako formirane, skraćene skale imale su sljedeće koeficijente pouzdanosti (Cronbach alpha): 0,67, 0,77 i 0,71.

Kontrolni popis emocionalne regulacije $e^{40}$ - validiran je za potrebe ovog istraživanja. Izvorno ima 24 tvrdnje. Faktorskom analizom potvrđena je dvofaktorska struktura kontrolnog popisa, ali su se faktorske projekcije nekih tvrdnji razlikovale od izvorne inačice upitnika. Formirani su rezultati za supskale: labilnost/negativnost (Pokazuje velike promjene raspoloženja; 2., 4., 5., 6., 8., 12., 13., 14., 20., 22.) i regulaciju emocija (Može odgoditi zadovoljenje potreba; 1., 3., 7., 9., 10., 11., 15., 16., 18., 19., 21., 24). Koeficijenti pouzdanosti iznosili su: 0,85 i 0,79 .

Roditelji su procjenjivali koliko se tvrdnje odnose na njihovo dijete (1 - uopće nije točno, 5 - u potpunosti točno).

Upitnik roditeljskog ponašanja $a^{41}$ - ima 29 tvrdnji, a mjeri roditeljsku podrš$\mathrm{ku}$ (Uvažavam i poštujem svoje dijete kao osobu), restriktivnu kontrolu (Vičem kad se dijete loše ponaša) i popustljivost (Popustljiv sam prema djetetu). Faktorska analiza je potvrdila definirane globalne dimenzije roditeljskog ponašanja, s tim da je 20. tvrdnja, umjesto na roditeljskoj podršci, imala projekciju na restriktivnoj kontroli. Koeficijenti pouzdanosti iznosili su 0,80, 0,72 i 0,72.

Skala osjećaja roditeljske kompetentnosti ${ }^{42}$ - sadrži 17 tvrdnji i mjeri zadovoljstvo roditeljstvom (Ponekad mi se čini da ništa ne mogu napraviti) i roditeljsku kompetentnost (Roditeljstvo je jednostavno i svi problemi se daju riješiti). Faktorska analiza je potvrdila dvofaktorsku strukturu, a koeficijenti pouzdanosti (Cronbach alpha) iznosili su: 0,79 i 0,78 . Roditelji su procjenjivali koliko se tvrdnje odnose na njih kao roditelje (1 - uopće nije točno, 5 - u potpunosti točno).

\footnotetext{
${ }^{39}$ Usp. S. PUTNAM, M. ROTHBART, Development of short and very short forms of the children's behavior questionnaire, Journal of personality assessment, 87 (2006) 1, 103-113.

${ }^{40}$ Usp. A. SHILDS, D. CICCHETTI, The development of an emotion regulation assessment battery: Reliability and validity among at-risk grade-school children, Indianapolis, IN, Poster session presented at the biennial meeting of the Society for Research in Child Development, March 1995.

${ }^{41}$ Usp. G. KERESTEŠ i dr., Razvoj i validacija upitnika roditeljskog ponašanja, Suvremena psihologija, 15 (2012) 1, 23-42.

${ }^{42}$ Usp. J. GIBAUD-WALLSTON, L. WANDERSMAN, Development and Utility of the Parenting Sense of Competence Scale, prema I. REIĆ ERCEGOVAC, Neki prediktori doživljaja roditeljstva majki i očeva djece dojenačke dobi, Napredak, 152 (2011) 2, 267-288.
} 


\subsection{Mjerni instrument primijenjen na uzorku odgojiteljica}

Ljestvica socioemocionalne dobrobiti i otpornosti ${ }^{43}$ - sadrži 37 tvrdnji i mjeri: samokontrolu (Poštuje granice $i$ želje druge djece), uživanje u istraživanju (Dijete istražuje nove stvari samostalno), asertivnost (Dijete je ustrajno u svojim inicijativama), emocionalnu inteligenciju (Inicira igre koje su drugoj djeci роželjne) i emocionalnu stabilnost (Djeluje dobro emocionalno uravnoteženo). Faktorske analize po pojedinim supskalama pokazale su zadovoljavajuća faktorska zasićenja, a koeficijenti pouzdanosti iznosili su: 0,90, 0,90, 0,85, 0,88, i 0,88 . Odgojiteljice su procjenjivale koliko se tvrdnje odnose na dijete $(1-$ uopće nije točno, 5 - u potpunosti točno).

\subsection{Mjerni instrument primijenjen kroz intervju s djecom koji su} vodile odgojiteljice

Upitnik za samoopis za predškolce ${ }^{44}$ - validiran za potrebe ovog istraživanja. Izvorno ima 38 pitanja, a u ovom istraživanju korišteno ih je 31. Mjeri šest područja: dva akademska (verbalno i matematičko) i četiri neakademska (fizičko, izgled, odnosi s vršnjacima i odnosi s roditeljima). Odgojiteljice su djeci postavljale pitanja (npr.: Sviđa li ti se kako izgledaš?) na koja su djeca odgovarala s DA ili NE. Nakon prvog odgovora postavlja se dodatno pitanje. Odgovori se bilježe pomoću ljestvice od 5 stupnjeva $(1-$ ne, uvijek, 2 - ne, ponekad, 3 - ne može se odlučiti, 4 - da, ponekad i 5 - da, uvijek). Faktorska analiza na zajedničke faktore pokazala je tri interpretabilna faktora: izgled (Jesi li zadovoljan svojim izgledom?; 7., 8., 9., 12.), odnosi (s vršnjacima i roditeljima; Imaš li puno prijatelja?; 13., 16., 17., 18., 21., 22., 23., 26.) i akademsko područje (verbalno i matematičko; Voliš li listati slikovnice i knjige?; 28., 30., 32., 34., 35., 36., 37., 38.). Koeficijenti pouzdanosti iznosili su: 0,75, 0,64 i 0,77.

\subsection{Postupak}

Istraživanje je provedeno uz suglasnost ravnatelja predškolskih ustanova, odgojiteljica i roditelja. Odgojiteljice su u predškolskim ustanovama upitnike podijelile roditeljima. Sudjelovanje je bilo dobrovoljno, te su oni roditelji koji su to željeli popunjene upitnike i potpisanu suglasnost za dijete vratili drugi dan.

\footnotetext{
${ }^{43}$ Usp. T. MAYR, M. ULICH, Social-emotional well-being and resilience of children in early childhood settings, prema S. TATALOVI VORKAPIĆ, D. LONČARIĆ, Validacija hrvatske verzije ljestvice socio-emocionalne dobrobiti i otpornosti predškolske djece, Hrvatska revija za rehabilitacijska istraživanja, 50 (2014) 2, 102-117.

${ }^{44}$ Usp. H. MARSH, L. ELLIS, R. CRAVEN, How do preschool children feel about themselves? Unraveling measurement and multidimensional self-concept structure, Developmental Psychology, 38 (2002) 3, 376-393.
} 
Odgojiteljice su obavile procjene i intervju s djecom, a podaci prikupljeni od roditelja i odgojiteljica povezani su šifrom.

\section{Rezultati i rasprava}

Prvi korak u obradi podataka bio je ispitati navike korištenja medija (televizije, računala, mobitela i tableta) kod djece predškolske dobi.

Tablica 1. Odgovori roditelja na pitanje koliko vremena u jednom prosječnom danu dijete provede na TV, računalu, mobitelu i tabletu, frekvencije i postoci

\begin{tabular}{|l|c|c|c|c|c|c|c|c|}
\hline \multirow{2}{*}{} & \multicolumn{2}{|c|}{ TV } & \multicolumn{2}{c|}{ računalo } & \multicolumn{2}{c|}{ mobitel } & \multicolumn{2}{c|}{ tablet } \\
\cline { 2 - 9 } & f & $\mathbf{\%}$ & f & \% & f & \% & f & \% \\
\hline Manje od pola sata & 88 & 22,51 & 191 & 48,85 & 174 & 44,50 & 165 & 42,20 \\
\hline 1 sat & 172 & 43,99 & 30 & 7,67 & 75 & 19,18 & 51 & 13,04 \\
\hline 2 sata & 89 & 22,76 & 8 & 2,05 & 31 & 7,93 & 15 & 3,84 \\
\hline Više od 2 sata & 26 & 6,65 & 2 & 0,51 & 10 & 2,55 & 6 & 1,53 \\
\hline Ne koristi & 16 & 4,09 & 160 & 40,92 & 101 & 25,83 & 154 & 39,38 \\
\hline
\end{tabular}

Na temelju podataka prikazanih u tablici 1. vidimo da najveći postotak djece vrijeme provodi gledajući televiziju i to najviše jedan sat dnevno, zatim na mobitelu, manje od pola sata dnevno. Gotovo $60 \%$ djece koristi računalo i tablet - i to manje od pola sata dnevno. Za $45 \%$ djece utvrđeno je da koriste sva četiri uređaja. Ovi nalazi su u skladu s rezultatima sličnih istraživanja provedenih u Hrvatskoj. ${ }^{45}$

Tablica 2. Prosječna dob početka korištenja pojedinog uređaja

\begin{tabular}{|l|c|c|c|c|}
\hline & TV & računalo & mobitel & tablet \\
\hline $\begin{array}{l}\text { Prosječna dob kada su djeca počela } \\
\text { koristiti pojedini uređaj }\end{array}$ & 2,16 & 4,08 & 3,75 & 4,11 \\
\hline
\end{tabular}

U prosjeku djeca su televiziju počela gledati s 2 godine, a mobitel, računalo i tablet s 4 godine. Većina djece $(65,73 \%)$ na televiziji gleda isključivo programe namijenjene djeci, dok $31,71 \%$ gleda i ostale programe. Internetom se samostalno služi $43,22 \%$ djece.

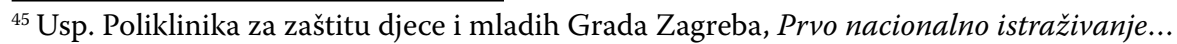


Tablica 3. Odgovori roditelja na pitanje što dijete najčešće radi na računalu, frekvencije i postoci

\begin{tabular}{|l|c|c|}
\hline & f & \% \\
\hline igra igrice & 87 & 22,25 \\
\hline gleda video uratke & 52 & 13,30 \\
\hline sluša glazbu ili glazbene videe & 36 & 9,21 \\
\hline pregledava edukativne sadržaje & 15 & 3,84 \\
\hline gleda crtiće & 128 & 32,74 \\
\hline bez odgovora & 73 & 18,67 \\
\hline
\end{tabular}

Djeca računalo najčešće koriste za zabavu (gledaju crtiće i igraju igrice), a najmanji postotak djece gleda edukativne sadržaje na računalu. Na pitanje roditeljima jesu li postavili ograničenja na uređaje koje dijete koristi, od roditelja koji su odgovorili na ovo pitanje, gotovo polovica njih (48,29 \%) nije postavilo ograničenje (oko $20 \%$ smatra da za to nema potrebe ili da je dijete premaleno pa ne treba ograničenja).

Tablica 4. Odgovori roditelja na pitanje ima li dijete ograničeno vrijeme koje smije provesti na TV, računalu, mobitelu i tabletu, frekvencije i postoci

\begin{tabular}{|l|c|c|}
\hline & f & \% \\
\hline ima strogo ograničeno vrijeme kad i kako ga smije koristiti & 105 & 26,85 \\
\hline dogovorili smo se da ne bi smjelo biti dugo & 162 & 41,43 \\
\hline kada vidim da je predugo na uređaju, oduzmem mu ga & 105 & 26,85 \\
\hline nema ograničenja & 7 & 1,79 \\
\hline nedostaje odgovor & 12 & 3,07 \\
\hline
\end{tabular}

Roditelji se uglavnom dogovaraju s djecom o korištenju uređaja, jedna četvrtina je postavila stroga ograničenja i isto toliko roditelja oduzme uređaj ako ga dijete predugo koristi, što ukazuje na postojanje restriktivne medijacije. Roditelji svoju informatičku pismenost procjenjuju vrlo dobrom $(\mathrm{M}=4,21, \mathrm{SD}=0,78)$, ali nemaju jasno definiran stav prema dječjem korištenju medija (niti negativan niti pozitivan, $M=2,84, S D=0,92)$, iako je više negativan. 
Tablica 5. Deskriptivna statistika za mjerene varijable

\begin{tabular}{|l|l|c|}
\hline ukupno vrijeme korištenja medija & & M (SD) \\
\hline \multirow{4}{*}{ temperament } & Surgencija & $2,67(1,19)$ \\
\cline { 2 - 3 } & Negativan afekt & $3,49(0,66)$ \\
\cline { 2 - 3 } regulacija emocija & Kontrola ulaganja napora & $2,74(0,64)$ \\
\hline \multirow{4}{*}{$\begin{array}{l}\text { socioemocionalna dobrobit i } \\
\text { otpornost }\end{array}$} & Labilnost & $4,16(0,53)$ \\
\cline { 2 - 3 } & Regulacija emocija & $2,06(0,66)$ \\
\hline \multirow{4}{*}{ samopoimanje } & Samokontrola (SK) & $4,25(0,45)$ \\
\cline { 2 - 3 } & Uživanje u istraživanju (UI) & $3,96(0,77)$ \\
\cline { 2 - 3 } & Asertivnost (A) & $4,04(0,68)$ \\
\cline { 2 - 3 } & Emocionalna inteligencija (EI) & $4,05(0,67)$ \\
\cline { 2 - 3 } & Emocionalna stabilnost (ES) & $3,99(0,69)$ \\
\hline \multirow{3}{*}{ roditeljsko ponašanje } & Izgled (I) & $3,42(0,76)$ \\
\cline { 2 - 3 } & Odnosi (O) & $4,55(0,60)$ \\
\cline { 2 - 3 } & Akademsko samopoimanje (AS) & $4,20(0,59)$ \\
\hline \multirow{2}{*}{ roditeljska kompetentnost } & Roditeljska podrška & $4,52(0,32)$ \\
\cline { 2 - 3 } & Restriktivna kontrola & $2,89(0,60)$ \\
\cline { 2 - 3 } & Popustljivost & $2,69(0,77)$ \\
\hline & Zadovoljstvo roditeljstvom & $4,11(0,58)$ \\
\cline { 2 - 3 } & Roditeljska kompetentnost & $3,54(0,61)$ \\
\hline
\end{tabular}

$\mathrm{Na}$ temelju odgovora roditelja o dječjem korištenju svakog pojedinog uređaja, izračunali smo ukupno vrijeme koje djeca dnevno provedu koristeći medije. Varijanca odgovora je umjetno smanjena jer je odgovor više od dva sata tretiran kao dva sata. Vidimo da djeca u jednom danu preko tjedna različite uređaje prosječno koriste oko tri sata. Čak 57 \% djece predškolske dobi provodi više od maksimalno dopuštena dva sata dnevno koristeći različite uređaje. Prema procjenama roditelja, djeca pokazuju umjerenu razinu surgencije (pozitivne afektivnosti) i negativne afektivnosti, relativno visoku razinu kontrole ulaganja napora, nisku razinu labilnosti, a visoku razinu regulacije emocija. Prema procjenama odgojiteljica, djeca pokazuju umjerenu do relativno visoku razinu socioemocionalne dobrobiti i otpornosti. Djeca daju relativno visoke i vrlo visoke procjene samopoimanja. Nadalje, roditelji smatraju da daju vrlo visoku podršku, umjereno koriste restriktivnu kontrolu, te da su umjereno popustljivi. Pokazuju višu razinu zadovoljstva roditeljstvom i umjerenu razinu roditeljske kompetentnosti. 
Tablica 6. Povezanost (Spearmanov koeficijent korelacije) vremena provedenog $u$ korištenju medija i osobnih i okolinskih varijabli

\begin{tabular}{|l|c|c|c|c|c|}
\hline & TV & računalo & mobitel & tablet & $\begin{array}{c}\text { ukupno } \\
\text { vrijeme }\end{array}$ \\
\hline spol djeteta & $-0,09$ & $-0,00$ & $-0,01$ & $-0,09$ & $-0,10^{*}$ \\
\hline dob djeteta & $-0,06$ & 0,09 & $-0,03$ & $-0,04$ & 0,06 \\
\hline surgencija & $-0,05$ & 0,05 & $-0,04$ & 0,08 & 0,06 \\
\hline negativan afekt & $0,18^{*}$ & 0,02 & 0,00 & 0,12 & $0,13^{*}$ \\
\hline kontrola ulaganja napora & $-0,08$ & 0,05 & $-0,10$ & $-0,03$ & $-0,08$ \\
\hline labilnost & 0,08 & 0,08 & $-0,04$ & 0,08 & 0,06 \\
\hline regulacija emocija & $-0,00$ & $-0,07$ & $-0,04$ & $-0,17^{*}$ & $-0,11^{*}$ \\
\hline samokontrola & 0,04 & $-0,17^{*}$ & $-0,07$ & 0,01 & 0,02 \\
\hline uživanje u istraživanju & $-0,06$ & $-0,11$ & $-0,19^{*}$ & $-0,12$ & $-0,04$ \\
\hline asertivnost & $-0,10$ & $-0,02$ & $-0,13^{*}$ & $-0,13^{*}$ & $-0,04$ \\
\hline emocionalna inteligencija & $-0,07$ & $-0,15^{*}$ & $-0,16^{*}$ & $-0,12$ & $-0,06$ \\
\hline emocionalna stabilnost & $-0,08$ & $-0,16^{*}$ & $-0,05$ & $-0,05$ & 0,00 \\
\hline izgled & $-0,11^{*}$ & $-0,11$ & $-0,09$ & $-0,01$ & $-0,09$ \\
\hline odnosi & $-0,17^{*}$ & $-0,09$ & $-0,12^{*}$ & $-0,08$ & $-0,09$ \\
\hline akademsko samopoimanje & $-0,13^{*}$ & $-0,09$ & $-0,19^{*}$ & $-0,15^{*}$ & $-0,08$ \\
\hline dob roditelja & 0,05 & $-0,03$ & $-0,09$ & $-0,06$ & 0,01 \\
\hline obrazovanje majke & $-0,13^{*}$ & $-0,13$ & $-0,25^{*}$ & $-0,22^{*}$ & $-0,22^{*}$ \\
\hline obrazovanje oca & $-0,10$ & $-0,02$ & $-0,26^{*}$ & $-0,17^{*}$ & $-0,17^{*}$ \\
\hline zaposlenost roditelja & 0,03 & $-0,03$ & 0,07 & $0,24^{*}$ & 0,03 \\
\hline mjesto življenja & $-0,01$ & $-0,17^{*}$ & $-0,32^{*}$ & $-0,11$ & $-0,08$ \\
\hline broj djece & $0,11^{*}$ & $-0,04$ & $-0,04$ & $-0,05$ & 0,03 \\
\hline roditeljska podrška & $-0,16^{*}$ & 0,10 & $-0,09$ & $-0,09$ & $-0,07$ \\
\hline restriktivna kontrola & 0,08 & 0,05 & 0,03 & 0,01 & 0,02 \\
\hline popustljivost & $0,11^{*}$ & 0,10 & $0,25^{*}$ & 0,12 & $0,16^{*}$ \\
\hline zadovoljstvo roditeljstvom & $-0,20^{*}$ & $-0,03$ & $-0,11$ & $-0,02$ & $-0,10$ \\
\hline roditeljska kompetentnost & $-0,01$ & 0,06 & 0,05 & 0,06 & 0,03 \\
\hline roditeljska informatička pismenost & $-0,19^{*}$ & $-0,01$ & $-0,18^{*}$ & $-0,10$ & $-0,17^{*}$ \\
\hline stav o dječjem korištenju medija & 0,03 & 0,12 & $0,12^{*}$ & 0,06 & $0,15^{*}$ \\
\hline korištenje ograničenja & $-0,03$ & 0,05 & 0,00 & 0,08 & $-0,07$ \\
\hline & & & & \\
\hline
\end{tabular}

Iz tablice korelacija vidimo relativno malen broj značajnih koeficijenata (39), te su povezanosti relativno slabe. Više vremena pred televizorom provode djeca $\mathrm{s}$ većom negativnom afektivnošću i nižim samopoimanjem, djeca manje obrazovanih majki, u obitelji s većim brojem djece, djeca sa slabijom roditeljskom podrškom, većom popustljivošću, djeca roditelja manje zadovoljnih roditeljstvom i manje informatički pismenih roditelja.

Ovi nalazi su očekivani. Lošija socioemocionalna dobrobit i otpornost (slabija samokontrola, emocionalna inteligencija i emocionalna stabilnost), te život na selu povezani su s više vremena provedenog u korištenju računala. 
Iako su druga istraživanja pokazala da djeca sa sela ${ }^{46}$ manje koriste računalo, naši nalazi nisu neočekivani jer djeca medije koriste isključivo radi zabave, a na selu su vjerojatnije djeca iz siromašnijih obitelji, što je u skladu s nalazima Kabali i suradnika. ${ }^{47}$ Lošija socioemocionalna dobrobit i otpornost (slabije uživanje $u$ istraživanju, asertivnost i emocionalna inteligencija) povezani su i s korištenjem mobitela, što vrijedi i za lošije samopoimanje (odnosi i akademsko samopoimanje). Također, mobitel više koriste djeca manje obrazovanih roditelja, djeca koja žive na selu, te djeca manje informatički pismenih, popustljivijih roditelja i roditelja koji imaju pozitivniji stav prema korištenju medija. Tablet više koriste djeca sa slabijom regulacijom emocija, asertivnošću i lošijim akademskim samopoimanjem, djeca manje obrazovanih i nezaposlenih roditelja.

$\mathrm{Na}$ kraju, ukupno više vremena u korištenju svih medija provedu dječaci, djeca s izraženijom negativnom afektivnošću, slabijom regulacijom emocija, djeca manje obrazovanih, popustljivijih, slabije informatički pismenih roditelja i roditelja koji imaju pozitivniji stav prema dječjem korištenju medija. Da bismo provjerili koji skup prediktora najbolje predviđa vrijeme korištenja svih medija, provedena je regresijska analiza. U regresijsku analizu uvedeni su prediktori koji su pokazali povezanost s provođenjem vremena u korištenju bilo kojeg uređaja (tablica 6), a u tablici 7 prikazani su rezultati završnog koraka analize.

Tablica 7. Rezultati regresijske analize s ukupnim vremenom korištenja medija kao kriterijskom varijablom (završni korak)

\begin{tabular}{|l|c|}
\hline \multicolumn{1}{|c|}{ Prediktori } & $\boldsymbol{\beta}$ \\
\hline Obrazovanje majke & $-0,20$ \\
\hline Popustljivost & 0,14 \\
\hline Negativan afekt & 0,11 \\
\hline Odnosi & $-0,16$ \\
\hline Stav o medijima & 0,15 \\
\hline $\mathrm{R}=0,36, \mathrm{R}^{2}=0,13, \mathrm{~F}_{(5,308)}=9,24, \mathrm{p}=0,00$ & \\
\hline
\end{tabular}

Značajni prediktori ukupnog vremena korištenja medija su obrazovanje majke, popustljivost roditelja, negativan afekt, zadovoljstvo odnosima s roditeljima i vršnjacima i roditeljski stav o medijima. Više vremena u korištenju medija provode djeca manje obrazovanih majki, popustljivijih roditelja, djeca s izraženijim negativnim afektom, ona koju su manje zadovoljna odnosima s roditeljima i vršnjacima i djeca roditelja koji imaju pozitivniji stav prema dječjem korištenju medija. Ovaj skup prediktora objašnjava skromnih 13 \% varijance vremena provedenog u korištenju medija.

\footnotetext{
${ }^{46}$ Usp. Ilišin, Djeca i mediji..., 162.

${ }^{47}$ Usp. Kabali, Exposure and use of mobile media...
} 


\section{Zaključak}

Rezultati provedenog istraživanja u skladu su s rezultatima dosadašnjih istraživanja o izloženosti predškolske djece medijima, s tim da je povećano vrijeme korištenja mobitela i ukupno vrijeme korištenja medija. Smatramo da je to vrijeme i dulje ako uzmemo u obzir nedostatke procjena (roditelja) i smanjenja varijance zbog načina odgovaranja u ovom istraživanju. Rezultati pokazuju slabu, ali značajnu povezanost s osobnim čimbenicima (spol, temperament, regulacija emocija, socioemocionalna dobrobit i otpornost i samopoimanje) te okolinskim (obrazovanje i zaposlenost roditelja, mjesto življenja, broj djece u obitelji, roditeljsko ponašanje, zadovoljstvo roditeljstvom, informatička pismenost i stav o dječjem korištenju medija). Više je značajnih koeficijenata utvrđeno za uređaje koje djeca češće koriste, što ukazuje na to da mediji imaju stanovitu ulogu u razvoju djece, odnosno da korištenje medija dijelom ovisi i o osobnim i okolinskim čimbenicima. Neki od mogućih razloga utvrđene slabije povezanosti među varijablama mjerenim u ovom istraživanju mogu biti metodološke prirode, kao što su nedostaci procjena (posebice roditelja koji mogu biti subjektivni pri procjeni svoje djece), te činjenica da su podaci prikupljeni iz različitih izvora (od roditelja, odgajatelja i djece).

Također, moguće je da dob djece utječe na odnos između korištenja medija i osobnih i okolinskih čimbenika, što bi svakako trebalo provjeriti u budućim istraživanjima. Istraživanje također potvrđuje negativne odnose osobnih i okolinskih čimbenika s vremenom korištenja medija, odnosno ide u prilog istraživanjima koji govore o negativnom utjecaju medija na razvoj djece. To može biti odraz negativnog stava roditelja (a i javnosti) prema korištenju medija, odnosno o štetnom djelovanju medija na razvoj djece. Međutim, iako roditelji sebe smatraju vrlo dobro informatički pismenima, to ne znači da su i medijski pismeni, jer u istraživanju nažalost nije mjerena medijska pismenost. Bartaković i Sindik su utvrdili prosječnu informiranost roditelja o medijima, prosječno zajedničko gledanje televizije s djecom i nešto izraženiju instruktivnu medijaciju. ${ }^{48}$

Značajan postotak djece pred ekranima provodi više od maksimalno dopuštenog vremena, dio roditelja ne postavlja nikakva ograničenja ili koristi restriktivnu medijaciju, djeca medije koriste gotovo isključivo za zabavu, što može ukazivati na potrebu razvoja medijske pismenosti roditelja i kritičkog pristupa medijskim sadržajima, odnosno poticanje korištenja djeci primjerenih i edukativnih sadržaja. Istraživanje je provedeno na prigodnom uzorku, što treba uzeti u obzir prilikom interpretacije rezultata. Budući da su korelati vremena korištenja različitih uređaja donekle različiti, u budućim istraživanjima svakako bi trebalo uključiti i sadržaje koji se koriste na pojedinom uređaju, te njihovu ulogu između antecedenti (npr. spola, temperamenta djeteta itd.) i razvojnih ishoda (npr. socioemocionalne dobrobiti, slike o sebi itd.).

\footnotetext{
${ }^{48}$ Usp. Bartaković, Sindik, Medijacijska uloga roditelja...
} 


\section{Slavica Šimić Šašić* - Marija Rodić*** \\ Correlates of Media Use in Preschool Children}

\section{Summary}

The aim of the study was to examine the relationship between the amount of time spent using media in preschool children and some personal and environmental factors. The study involved 391 children, aged 5 to 7 years. Parents assessed media use, temperament and emotion regulation in children, parental behaviors toward the child and parental competence. Kindergarten teachers assessed children's socio-emotional well-being and resilience, and collected assessments of self-concept through interviews with children. The obtained results show that the amount of time that preschool children spend in the use of media is weakly but statistically significantly related to personal and environmental factors. Child gender, negative affect, emotion regulation, parental education, permissiveness, computer literacy and attitudes toward children's media use are related to the total time spent in media use. The correlates of time spent in media use vary depending on the type of media. The results of this research indicate the need for further research on the role of the media between the antecedent variables and developmental outcomes.

Key words: media, parents, personal and environmental factors, preschool children.

(na engl. prev. Slavica Šimić Šašić)

\footnotetext{
* Slavica Šimić Šašić, PhD, Assoc. Prof., University of Zadar, Department of Teachers and Preschool Teachers Education; Address: Ulica dr. F. Tuđmana 24i, HR-23000 Zadar, Croatia; Email: ssimic@unizd.hr.

**Marija Rodić, Mag. Paed. University of Zadar, Department of Teachers and Preschool Teachers Education; Address: Ulica dr. F. Tuđmana 24i, HR-23000 Zadar, Croatia; E-mail: marijarodic1@outlook.com.
} 